\title{
Immunotherapy With Interferon $\alpha 11$, But Not Interferon Beta, Controls Persistent Retroviral Infection
}

\author{
Mara Schwerdtfeger ${ }^{1}$, Julia Dickow ${ }^{1}$, Yasmin Schmitz ${ }^{1}$, Sandra Francois ${ }^{1}$, \\ Zehra Karakoese $^{1,2}$, Anna Malyshkina ${ }^{1}$, Torben Knuschke ${ }^{3}$, Ulf Dittmer ${ }^{1,2}$ \\ and Kathrin Sutter ${ }^{1,2 *}$ \\ ${ }^{1}$ Institute for Virology, University of Duisburg-Essen, Essen, Germany, ${ }^{2}$ Institute for Translational HIV Research, University of \\ Duisburg-Essen, Essen, Germany, ${ }^{3}$ Institute for Medical Microbiology, University Hospital Essen, University of Duisburg- \\ Essen, Essen, Germany
}

OPEN ACCESS

Edited by:

Julia G. Prado,

IrsiCaixa, Spain

Reviewed by:

Nuria Izquierdo-Useros,

IrsiCaixa, Spain

Liang Cheng,

Wuhan University, China

${ }^{*}$ Correspondence:

Kathrin Sutter

Kathrin.sutter@uni-due.de

Specialty section:

This article was submitted to

Viral Immunology,

a section of the journal

Frontiers in Immunology

Received: 05 November 2021

Accepted: 29 December 2021

Published: 20 January 2022

Citation:

Schwerdtfeger M, Dickow J,

Schmitz Y, Francois S, Karakoese Z,

Malyshkina A, Knuschke T,

Dittmer U and Sutter K (2022)

Immunotherapy With Interferon $\alpha 11$,

But Not Interferon Beta, Controls

Persistent Retroviral Infection.

Front. Immunol. 12:809774.

doi: 10.3389/fimmu.2021.809774
Type I Interferons (IFNs), including numerous IFN $\alpha$ subtypes and IFN $\beta$, are key molecules during innate and adaptive immune responses against viral infections. These cytokines exert various non-redundant biological activities, although binding to the same receptor. Persistent viral infections are often characterized by increased IFN signatures implicating a potential role of type I IFNs in disease pathogenesis. Using the well-established Friend retrovirus (FV) mouse model, we compared the therapeutic efficacy of IFN $\alpha 11$ and IFN $\beta$ in acute and chronic retroviral infection. We observed a strong antiviral activity of both IFNs during acute FV infection, whereas only IFN $\alpha 11$ and not IFN $\beta$ could also control persistent FV infection. The therapeutic treatment with IFN 111 induced the expression of antiviral IFN-stimulated genes (ISG) and improved cytotoxic T cell responses. Finally, dysfunctional $\mathrm{CD}^{+} \mathrm{T}$ cells solely regained cytotoxicity after IFN $\alpha 11$ treatment. Our data provide evidence for opposing activities of type I IFNs during chronic retroviral infections. IFN $\beta$ was shown to be involved in immune dysfunction in chronic infections, whereas IFN $\alpha 11$ had a strong antiviral potential and reactivated exhausted $T$ cells during persistent retroviral infection. In contrast, during acute infection, both type I IFNs were able to efficiently suppress FV replication.

Keywords: Type I IFNs, retroviral infection, Friend retrovirus, persistent infection, immunotherapy, cytotoxic CD8 ${ }^{+}$ T cells

\section{INTRODUCTION}

Type I IFNs belong to a multigene family consisting of numerous IFN $\alpha$ subtypes but only one IFN $\beta$,

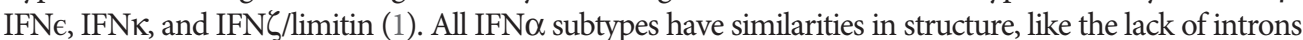
or the length of the protein (161-167 amino acids), and their protein sequence is highly conserved (75 $99 \%$ amino acid sequence identity) $(2,3)$. Interestingly, they all bind to the same ubiquitously expressed IFN $\alpha / \beta$ receptor (IFNAR), but their biological activities differ (4). Binding to the receptor leads to the activation of the classical Jak-STAT-signalling cascade, however also other signalling pathways become 
activated upon type I IFN binding [reviewed in (5)]. As a consequence, numerous and partly subtype-specific ISGs are transcribed with direct antiviral, immunomodulatory, but also regulatory properties.

IFN $\alpha 2$ is used in clinical applications since 1983. Interestingly, it is still the only subtype used for IFN $\alpha$ therapy to date. In contrast to most antiviral drugs, IFN $\alpha$ does not only prevent viral infection of cells, but it is also able to eliminate virus from host cells. For many years, IFN $\alpha 2$ has been used as the standard therapy for hepatitis $\mathrm{C}$ virus (HCV) infections alone or in combination with other antiviral drugs. Due to the development of more effective therapies with direct-acting antivirals, IFN-based therapy against chronic hepatitis $\mathrm{C}$ was no longer recommended in 2016. However, IFNo2 is still the standard treatment option for chronic hepatitis B patients, but only about $30 \%$ of patients respond to the therapy, of which only a few patients show complete viral clearance (6). IFN $\alpha 2$ has wellknown adverse effects, which lead to discontinuance in approximately $15 \%$ of patients. Many clinical trials have analyzed the therapeutic potency of IFN $\alpha 2$ as monotherapy or in combination with antiretroviral therapy against HIV (7-9), but the therapeutic outcome was disappointing. We could recently show, using HIV-infected PBMCs and LPMCs as well as in HIV-infected humanized BLT mice, that other IFN $\alpha$ subtypes are much more potent in restricting HIV replication than IFN $\alpha 2(10,11)$. Combination therapy of antiretroviral drugs together with IFN $\alpha 14$ further reduced the viral loads in chronically HIV-infected humanized mice (12), suggesting that IFN therapy with the right subtype (increased antiviral and immunomodulatory activity, reduced side effects) might still be an option to treat HIV infection. We found that IFN $\alpha 14$ reduced viral loads and improved NK cell responses in acutely HIVinfected humanized BLT mice with no sign of $\mathrm{T}$ cell hyperactivation or dysfunction (10). Furthermore, IFN $\alpha 14$ treatment during established HIV infection of humanized BLT mice in combination with antiretroviral treatment further reduced viral loads (12). However, for chronic HIV infection type I IFN induced hyperimmune activation is still controversially discussed $(9,13-18)$. Several studies showed that a type I IFN signature in chronically HIV-infected humanized mice was associated with $\mathrm{T}$ cell dysfunction and a lack of immune control of the virus (19-21). They suggested that IFN therapy might be detrimental during chronic HIV infection, but they did not distinguish between IFN $\beta$ and IFN $\alpha$ responses. Previous reports on chronic lymphocytic choriomeningitis virus (LCMV) infection of mice confirmed an antiviral role of type I IFNs during acute infection, but a rather detrimental role during chronic LCMV infection $(22,23)$. They reported that type I IFNs initiate an immunosuppressive program that represses antiviral immunity and facilitates persistent LCMV infection. However, the same authors showed some years later, that only IFN $\beta$ and not IFN $\alpha$ impaired antiviral immunity and supported persistent LCMV infection (24). Thus, IFN $\alpha$ might still be an option for the treatment of chronic infections, including HIV.

Using the well-established Friend retrovirus (FV) mouse model, we aimed to analyze the therapeutic potential of different type I IFNs during acute and chronic retroviral infections. The FV complex is comprised of two retroviruses: the replication-competent helper virus called Friend murine leukemia virus (F-MuLV), which is non-pathogenic in adult mice, and the replication-defective, pathogenic spleen focusforming virus (SFFV) (25). FV induces erythroleukemia in susceptible mice. In contrast, resistant strains, such as the C57BL/6 mice that were used in the current study, mount potent immune responses during acute infection and recover from disease (26), but the viral control is incomplete leading to a life-long chronic FV infection. In the present study we addressed the distinct and non-redundant roles of IFN $\alpha$ and IFN $\beta$ during acute and chronic retroviral infection. Murine IFN $\alpha 11$, which was previously shown to efficiently control acute FV infection and improve NK cell effector functions (27), was selected from the IFN $\alpha$ subtype family for this comparison. Interestingly, therapeutic application of IFN $\alpha$ and IFN $\beta$ was effective in controlling acute FV infection, but only IFN $\alpha$ suppressed viral replication during chronic FV infection.

\section{MATERIAL AND METHODS}

\section{Mice, Peptide and Virus}

Female C57BL/6 mice were purchased from Envigo. All mice used for experiments were at least 8 weeks of age and were followed by the ARRIVE guidelines and maintained in accordance with the regulations and guidelines of the institutional animal care and use committee of the University of Duisburg-Essen, Germany. Peptide derived from the FV Gag protein (sequences: CCLCLTVFL) (28) was used for the in vivo cytotoxicity assay.

The FV stock used in the experiments was a FV complex containing B-tropic F-MuLV and polycythemia-inducing SFFV. The stock was prepared as a $15 \%$ spleen cell homogenate from $\mathrm{BALB} / \mathrm{c}$ mice infected 14 days previously with 3,000 spleen focus-forming units (SFFU). Mice were infected intravenously with 20,000 SFFU for acute infection. For the development of chronic infection, additional 100,000 SFFU of F-MuLV were added. The stock was lactate dehydrogenase virus (LDV)-free.

\section{Expression of Type I IFN and Determination of IFN Concentrations}

Expression of IFN $\beta$ were performed as previously described (29). To produce murine IFN $\alpha 11$, the cell line HEK293mIFNalpha11 was cultivated as described (30). All concentrated supernatants were tested for type I IFN activity using the murine 3T3 ISRE Luc reporter cell line, transfected with a plasmid containing the Firefly Luciferase gene, stably integrated under control of the IFNstimulation-response element (ISRE). After $4.5 \mathrm{~h}$ of stimulation with IFN $\alpha$, cells were lysed and chemiluminescence was detected using the Beetle-Juice Luciferase assay Firefly (PJK). The IFN activity was calculated to the respective activity in units against commercially available recombinant mouse IFN $\beta$ and universal IFNo (PBL assay science). 


\section{In Vitro F-MuLV Inhibition Assay}

Mus dunni tail fibroblast cells were pre-treated in vitro for $24 \mathrm{~h}$ with increasing concentrations (10 - 10,000 units/ml) of IFN $\alpha 11$ or IFN $\beta$. Cells were then infected with 250 FFU of F-MuLV, cultivated for 3 days, fixed with ethanol, stained with F-MuLV envelope-specific monoclonal antibody 720, and developed with peroxidase-conjugated goat anti-mouse antibody and aminoethylcarbazol to detect viral foci (31).

\section{IFN $\alpha$ Subtype Treatment In Vivo}

Mice were injected intraperitoneally daily from days 5 to 9 during acute FV infection or days 40 to 44 of chronic FV infection with 8000 units of IFN $\alpha 11$ or IFN $\beta$. Mock-treated control mice were injected with the supernatant of HEK293T cells transfected with an empty vector. Ten days or 45 post infection, the mice were sacrificed and analyzed for viral loads and immune responses.

\section{Detection of Virus-Infected Cells}

Infectious center (IC) assays were performed on Mus dunni tail fibroblast cells as described previously (31). Briefly, titrations $\left(10^{7}-10^{2}\right.$ cells $\left./ \mathrm{mL}\right)$ of single-cell suspensions from infected mouse spleens were plated onto susceptible $M$. dunni cells, cocultivated for 3 days, and stained with F-MuLV envelope-specific monoclonal antibody 720 to detect foci.

\section{Cell Surface and Intracellular Staining by Flow Cytometry}

Cell surface and intracellular staining of spleen cells was performed as previously described $(32,33)$ using the following antibodies (BioLegend): anti-CD4 (GK1.5), anti-CD8 (53-6.7), anti-CD43 (1B11), anti-CD62L (MEL-14), anti-Granzyme B (GzmB; clone GB11), anti-IFN (XMG1.2), anti-IL-2 (JES6$5 \mathrm{H} 4)$ and anti-TNF $\alpha$ (MP6-XT22). For intracellular staining, the cells were treated with $10 \mu \mathrm{g} / \mathrm{mL}$ immobilized $\alpha \mathrm{CD} 3$ (1452C11), $2 \mu \mathrm{g} / \mathrm{mL} \alpha \mathrm{CD} 28$ (37.51) and $2 \mu \mathrm{g} / \mathrm{mL}$ Brefeldin $\mathrm{A}$ in RPMI medium (complemented with $50 \mu \mathrm{M} \beta$-mercaptoethanol) at $37^{\circ} \mathrm{C}$ for $5 \mathrm{~h}$. Dead cells were excluded from analysis (positive for fixable viability dye, Thermo Scientific). Fluorescence minus one (FMO) controls were used for all conditions. Data were acquired on a FACS LSR II flow cytometer (BD Biosciences) and analyses were performed using Flow Jo (BD Biosciences) software.

\section{RNA Isolation}

Total RNA was isolated from splenocytes utilizing Quick RNA Miniprep (Zymo Research). Isolated RNA was dissolved in $\mathrm{RNase}$-free water and stored at $-80^{\circ} \mathrm{C}$.

\section{Real-Time-PCR}

Real-time-PCR (RT-PCR) analysis for the quantification of Oas1a, $P k r$ and Isg15 mRNA was performed using PowrUp ${ }^{\text {TM }}$ SYBR $^{\circledR}$ Green Master Mix (Thermo Scientific) and QuantiTect Primer Assays (Qiagen) for all 3 genes. The quantitative mRNA levels were determined by using StepOne Software v2.3 (Thermo Scientific) and were normalized to $\beta$-actin mRNA (Primer forward: caagaaggaaggctggaaaa; Primer reverse: aaatcgtgcgtgacatcaaa) expression levels.

\section{IFN $\alpha$ Detection in Serum of FV-Infected Mice}

The levels of IFN $\alpha$ in the serum of FV-infected mice were detected by using LumiKine ${ }^{\mathrm{TM}}$ Xpress mIFN- $\alpha 2.0$ (In vivogen) according to the manufacturer's instructions.

To further determine IFN $\alpha$ and IFN $\beta$ levels in serum of treated mice, NIH 3T3 cells were seeded in 48-well plates in $10 \%$ DMEM and grown under standard cell culture conditions until $70 \%$ confluency. The ISRE-Luc reporter plasmid was prepared with polyethylenimine (PEI) in DMEM without FCS and incubated for $20 \mathrm{~min}$ at room temperature. Subsequently, the culture medium of the seeded cells was replaced by $500 \mu \mathrm{L}$ of DMEM supplemented with $2 \%$ FCS before applying equal amounts of the transfection mixture. The cells were incubated $16 \mathrm{~h}$ at $37^{\circ} \mathrm{C}$ before transfection. Afterwards, the cells were washed once and stimulated with mice serum (diluted 1:5) for $6 \mathrm{~h}$ at $37^{\circ} \mathrm{C}$. Then, cells were lysed and chemiluminescence was detected by the Beetle-Juice Luciferase assay Firefly (PJK).

\section{F-MuLV-Neutralizing Antibody Assay}

For analysis of neutralizing antibodies, plasma samples were inactivated for 30 minutes at $56^{\circ} \mathrm{C}$ and serially diluted with PBS. Plasma dilutions were mixed with purified F-MuLV and guinea pig complement (Sigma-Aldrich) and incubated for $1 \mathrm{~h}$ at $37^{\circ} \mathrm{C}$. Afterwards, the samples were added to Mus dunni cells which were plated in 24-well plates the day before. Cells were incubated to $\sim 100 \%$ confluency under standard tissue culture conditions and fixed and stained as described for the IFN $\alpha$ inhibition assay. Foci were counted and dilutions which resulted in at least $75 \%$ reduction of foci number were considered neutralizing.

\section{In Vivo Cytotoxicity Assay}

For the in vivo cytotoxicity assays, $2 \times 10^{6}$ splenocytes loaded with a peptide derived from the FV Gag protein (sequences: CCLCLTVFL) CellTrace ${ }^{\mathrm{TM}}$ Violet $^{\text {high }}(80 \mu \mathrm{M})$ labelled and $2 \mathrm{x}$ $10^{6}$ unloaded CellTrace $^{\mathrm{TM}}$ Violet $^{\text {low }}(2 \mu \mathrm{M})$ labelled splenocytes from naive $\mathrm{C} 57 \mathrm{BL} / 6$ mice were adoptively transferred into chronically FV-infected and IFN-treated mice (32). Naive C57BL/6 recipient mice were used as controls to calculate the elimination of target cells. Two hours post transfer, recipient mice were sacrificed and cells were stained with fixable viability dye. The percentage of target-specific killing was calculated as follows: 100 - ([(\% peptide pulsed CellTrace ${ }^{\mathrm{TM}}$ Violet $^{\mathrm{hi}}$ cells in adoptively transferred mice/\% unpulsed CellTrace ${ }^{\mathrm{TM}}$ Violet $^{\text {lo }}$ cells in adoptively transferred mice)/(\% peptide pulsed CellTrace $^{\mathrm{TM}}$ Violet $^{\text {hi }}$ cells in naive/\% unpulsed CellTrace ${ }^{\mathrm{TM}}$ Violet $^{\text {lo }}$ cells in naive)] $\mathrm{x} 100$ ).

\section{Statistical Analysis}

Experimental data were reported as means +SEM. Statistically significant differences between the IFN $\alpha$-treated groups and the untreated group were analyzed using Kruskal-Wallis one-way or 
Ordinary One-Way ANOVA analysis with Dunn's or Tukey's multiple comparison post hoc test. Statistical analyses were performed using GraphPad Prism software (GraphPad).

\section{RESULTS}

\section{Type I IFNs Inhibit Acute FV Infection In Vivo}

Type I IFNs are able to efficiently inhibit acute viral replication. It was already shown, that during acute LCMV infection type I IFNs contribute to the control of viral infection, whereas during chronic LCMV infection, IFN $\beta$, in contrast to IFN $\alpha$, has a rather detrimental role and contributed to immune dysfunction during persistent LCMV infection. As the role of type I IFNs during retroviral infections is still controversially discussed, we wanted to analyze the specific antiviral activity of IFN $\alpha$ and IFN $\beta$ during acute and chronic Friend retrovirus infection in vivo. Due to its previously shown high antiviral activity in FV infection, we chose IFN $\alpha 11$ as representative for IFN $\alpha$ in our study (27). Both IFNs were produced, purified and tested for their in vitro activity against commercially available IFNs using an ISRE Luc reporter cell line (Supplementary Figure 1). To determine their antiretroviral potential, we titrated both type I IFNs against F-
MuLV helper virus in vitro. Both type I IFNs efficiently suppressed F-MuLV replication in vitro, however IFN $\alpha 11$ was much more potent $\left(\mathrm{IC}_{50}: 128.9 \mathrm{U} / \mathrm{ml}\right)$ than $\mathrm{IFN} \beta\left(\mathrm{IC}_{50}: 468.4 \mathrm{U} /\right.$ $\mathrm{ml}$ ) in controlling F-MuLV infection (Figure 1A). Next, we infected $\mathrm{C} 57 \mathrm{BL} / 6$ mice with $\mathrm{FV}$ and therapeutically applied IFN $\alpha 11$ or IFN $\beta$ on five consecutive days starting at day 5 post infection (Figure 1B). At day 10 post infection, mice were sacrificed and viral loads in the spleen were determined. Both treatments (IFN $\alpha 11$ and IFN $\beta$ ) resulted in a significant reduction of viral replication compared to $\mathrm{FV}$-infected control mice (134-fold and 33-fold reduction, respectively) (Figure 1C). FV infection itself did not induce a systemic IFN $\alpha$ response, only a transient and low increase in Ifna mRNA expression in splenocytes 72 hours post FV infection was detected (29). Type I IFNs have a short half-life in vivo, so it was not surprising that 24 hours after the last IFN injection, levels of IFN $\alpha$ were similar between treated mice and FV-infected controls (Figure 1D). Furthermore, we also analyzed the serum concentrations of IFN $\alpha$ using an ELISA and both IFNs using a cell-based luciferase assay shortly after injection of the IFNs. ISREdependent luciferase activity was detected in all mice receiving IFN $\alpha 11$ and IFN $\beta$ after 30, 90, and 240 min post infection to similar extent (Supplementary Figure 2). Thus, there were no big differences in IFN bioavailability between the groups.
A

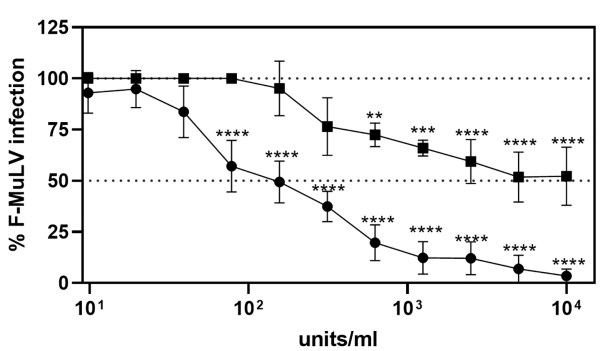

C

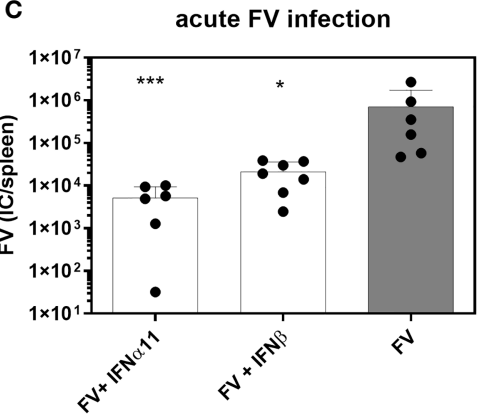

B
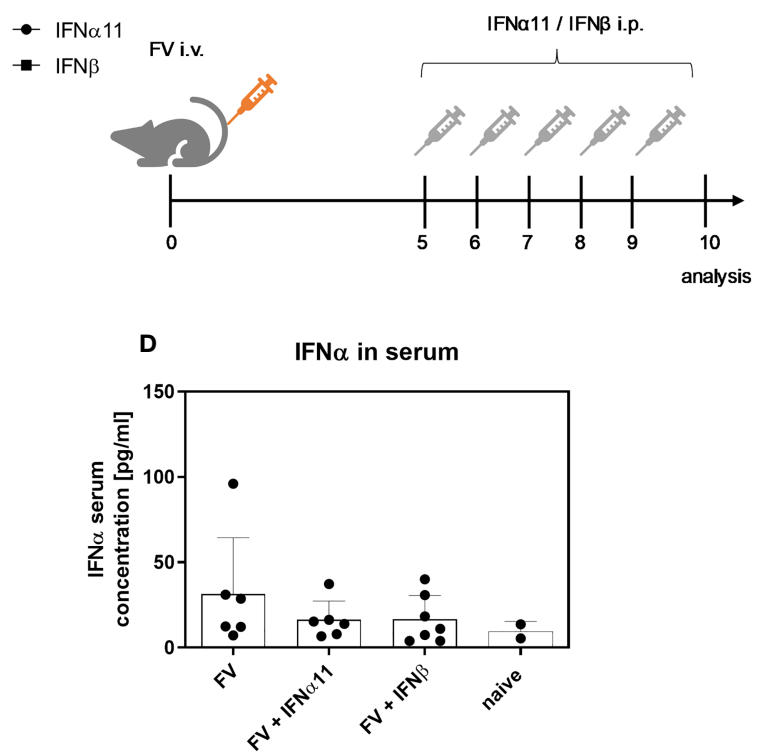

FIGURE 1 | Antiretroviral activity of IFN $\alpha 11$ and IFN $\beta$ during acute FV infection. (A) Antiretroviral activity of IFN $\alpha 11$ and IFN $\beta$ in vitro. Mus dunni cells were treated in

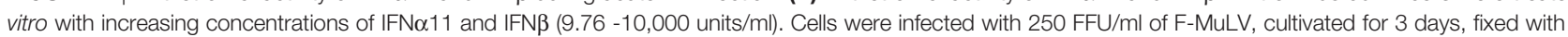
ethanol, stained with F-MuLV envelope-specific antibody 720 and foci were counted. F-MuLV titers were normalized to untreated controls as \% infection and are shown as mean + SEM ( $n=4)$. Statistically significant differences between the unstimulated cells (100\% infection) and the groups of IFN-stimulated cells (IFN $\alpha 11$ or

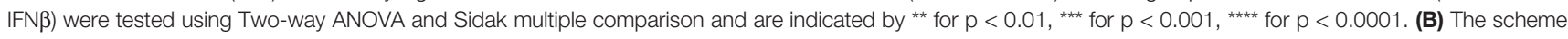
of the experimental timeline is shown. C57BL/6 mice were infected with 20,000 SFFU of FV from day +5 to +9 days post infection were treated daily with 8000 units of IFN $\alpha 11$ or IFN $\beta$. Ten dpi, viral loads were analyzed by an infectious center assay (C) and serum IFN $\alpha$ concentrations (D) were determined by ELISA. Six mice per FV-infected and IFN $\alpha 11$-treated group and 7 mice per IFN $\beta$-treated group were analyzed and the mean values for each group are indicated by a bar (+SEM). Data were pooled from two independent experiments with similar results. Statistically significant differences between the control group (FV) and the groups of IFN-treated mice (FV + IFN $\alpha 11$ or FV + IFN $\beta$ ) were tested using Kruskal-Wallis one-way and Dunn's multiple comparison and are indicated by * for $p<0.05$, ${ }^{\star \star \star}$ for $p<0.001$. 


\section{IFN $\alpha 11$, But Not IFN $\beta$, Efficiently Controlled Chronic FV Infection}

To elucidate the antiviral efficacy of type I IFNs during chronic FV infection, we infected C57BL/6 mice with FV and let chronicity develop. At day 40 post infection we started the treatment with IFN $\alpha 11$ or IFN $\beta$ on five consecutive days. At day 45 post infection, mice were sacrificed and spleens were analyzed for viral titers (Figure 2A). During acute FV infection, viral loads peak at $7 \mathrm{dpi}$ and further decreased steadily until a persistent low-level infection is established due to efficient CD8 effector $\mathrm{T}$ cell responses during acute FV infection (32). Therapeutic application of five doses of IFN $\alpha 11$ during chronic $\mathrm{FV}$ infection led to a significant reduction in viral loads (mean viral loads per spleen: 93), whereas treatment with IFN $\beta$ did not change viral titers (mean viral loads per spleen: 410 IC in IFN $\beta$ treated mice and 422 in untreated controls) (Figure 2B). Furthermore, we monitored the IFN signature during chronic FV infection by analyzing the expression of selected ISGs as well as the concentration of IFN $\alpha$ in the serum of chronically FVinfected mice. As shown in Figures 3A-C, chronic FV infection did not induce a significant expression of ISGs (Oas $1 a, P k r$, Isg15) in splenocytes compared to uninfected control mice. In contrast, treatment with IFN $\alpha 11$ significantly induced the mRNA expression of some ISGs (Oas1a, Isg15). Surprisingly, therapy with IFN $\beta$ did not alter the expression of the studied ISGs, indicating that only IFN $\alpha 11$, but not IFN $\beta$, induced a significant ISG response during chronic FV infection. Similar to acute FV infection, the virus itself did not induce a systemic IFN $\alpha$ responses, and also 24 hours post IFN-treatment no increased IFN $\alpha$ serum concentrations were found (Figure 3D). These data imply, that in contrast to acute FV infection, IFN $\beta$ could not control chronic FV infection. However, IFN $\alpha 11$ was able to suppress $F V$ replication during acute and chronic infection.

\section{Modest Immunomodulatory Effects of Type I IFNs on CD4 ${ }^{+}$T Cells}

Type I IFNs are defined by their antiviral properties, but they are also potent immunomodulators that can act directly on different cells of the innate and adaptive immune systems. Type I IFNs can modulate the activation, effector function, and survival of $\mathrm{T}$ cells (34-37). To clarify the biological activity of type I IFNs during chronic FV infection, we analyzed the influence of type I IFNs on $\mathrm{CD}^{+} \mathrm{T}$ helper cells during chronic FV infection. $\mathrm{CD} 4^{+} \mathrm{T}$ cells have no direct antiviral activity during acute $\mathrm{FV}$ infection; however, they are required for the control of chronic infection by mediating direct antiviral effects $(38,39)$. We observed a significant decrease in the numbers of $\mathrm{CD} 4^{+} \mathrm{T}$ cells in the spleen after treatment with both type I IFNs compared to untreated controls, but the numbers were still higher than in uninfected mice (Figure 4A). These results nicely confirm previous in vitro data, in which different IFN $\alpha$ subtypes reduced the proliferation of FV-specific T cells (37). Treatment with IFN $\alpha 11$ or IFN $\beta$ neither changed the frequencies of activated $\mathrm{CD} 4^{+} \mathrm{T}$ cells (Figure 4B), nor the frequencies of cytokine-producing $\mathrm{CD} 4^{+}$ $\mathrm{T}$ cells (Figures $\mathbf{4 E}-\mathbf{G}$ ) in comparison to untreated FV-infected control mice. However, IFN $\alpha$ - and IFN $\beta$-treatment significantly enhanced the percentages of cytotoxic $\mathrm{CD} 4^{+} \mathrm{T}$ cells, shown by the intracellular expression of $\mathrm{GzmB}$ as well as the individual GzmB expression per cell shown by mean fluorescence intensity (MFI) in activated $\mathrm{CD}^{+} \mathrm{T}$ cells (Figures $4 \mathrm{C}, \mathrm{D}$ ).

Apart from these cytotoxic $\mathrm{CD} 4^{+} \mathrm{T}$ cells, neutralizing antibodies are also important to keep viral replication in check (40-42). Furthermore, type I IFNs are able to enhance antibody responses (43-45). Thus, we determined the influence of type I IFNs treatment on neutralizing antibody responses. Therefore, serum samples of chronically FV-infected mice and IFN-treated mice were analyzed for their neutralizing capacity. We observed only a slight increase in neutralizing antibody titers against F-
A

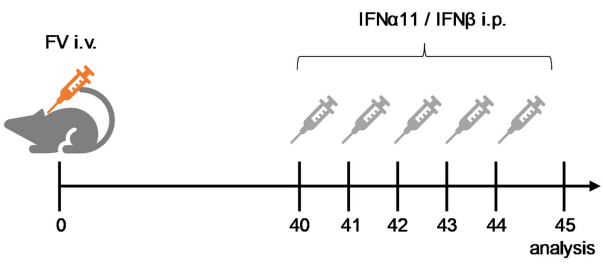

B

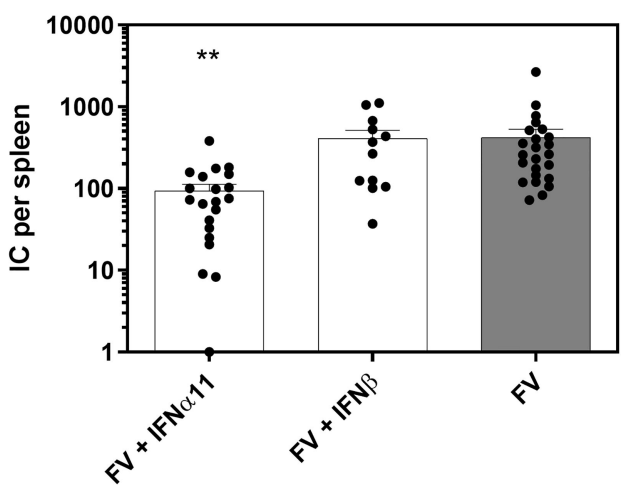

FIGURE 2 | Antiretroviral activity of IFN $\alpha 11$ and IFN $\beta$ during chronic FV infection. (A) The scheme of the experimental timeline is shown. C57BL/6 mice were infected with 20,000 SFFU of FV and additional 100,000 FFU of F-MuLV. Mice were treated daily with 8000 units of IFN 11 or IFN 3 from day 40 to 44 mice. At day 45 post infection, mice were sacrificed and viral loads were analyzed by an infectious center assay (B). 24 mice per FV-infected group, 21 mice per IFN 11 -treated group and 12 mice per IFN $\beta$-treated group were analyzed and the mean values for each group are indicated by a bar (+SEM). Data were pooled from four independent experiments with similar results. Statistically significant differences between the control group (FV) and the groups of IFN-treated mice (FV + IFN 11 or FV + IFNB) were tested using Kruskal-Wallis one-way and Dunn's multiple comparison and are indicated by ${ }^{* *}$ for $p<0.01$. 


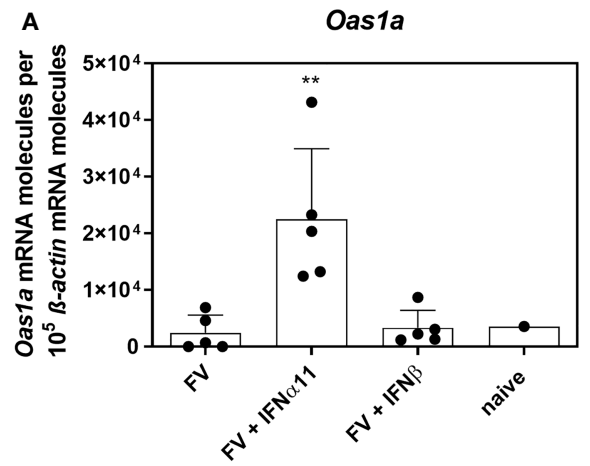

C

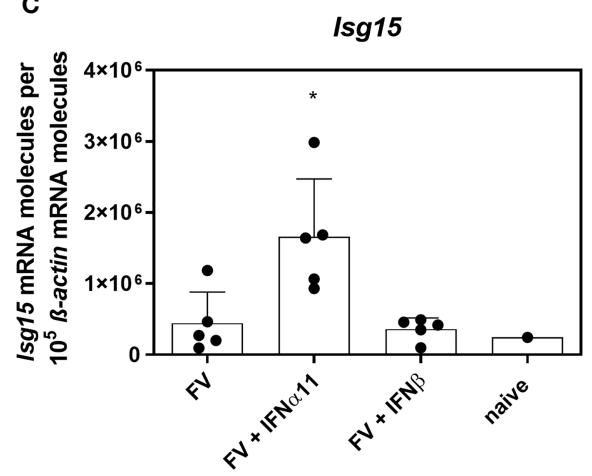

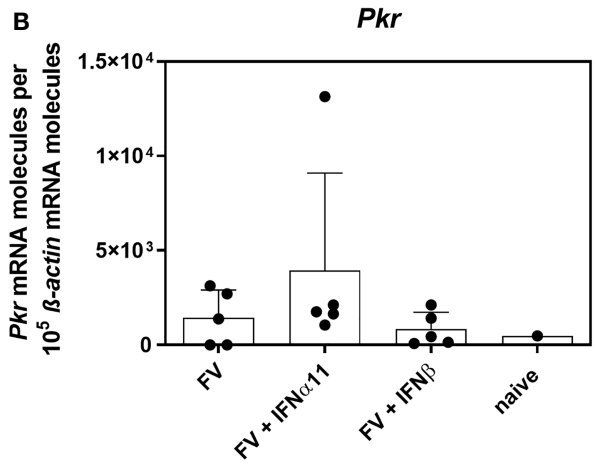

D

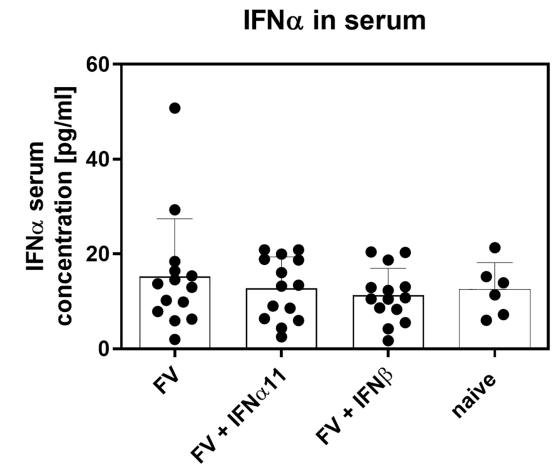

FIGURE 3 | IFN signature in chronically FV-infected mice. C57BL/6 mice were infected with 20,000 SFFU of FV and additional 100,000 FFU of F-MuLV. Mice were treated daily with 8000 units of IFN 11 or IFN $\beta$ from day 40 to 44 mice. At day 45 post infection, mice were sacrificed and splenocytes were analyzed for ISG mRNA expression (A-C). IFN $\alpha$ serum concentrations of chronically FV-infected mice were determined by ELISA at 45 dpi (D). Five mice per group (A-C) and 14 mice per group pooled from three independent experiments (D) were analyzed and the mean values for each group are indicated by a bar (+SEM). Statistically significant differences between the control group (FV) and the groups of IFN-treated mice (FV + IFN $\alpha 11$ or FV + IFN $\beta$ ) were tested using Kruskal-Wallis one-way and Dunn's multiple comparison and are indicated by ${ }^{\star} p<0.05,{ }^{\star \star} p<0.01$.

MuLV after IFN $\beta$ therapy, whereas treatment with IFN $\alpha$ did not affect neutralizing antibody titers (Supplementary Figure 3). In conclusion, we found only modest immunomodulatory effects of IFN $\alpha 11$ and IFN $\beta$ on $\mathrm{CD}^{+} \mathrm{T}$ cell and antibody responses, except for cytotoxic $\mathrm{T}$ cell responses.

\section{Dysfunctional CD8 ${ }^{+}$T Cells Regain Cytotoxic Activity Upon IFN 111 Treatment During Chronic FV Infection}

Cytotoxic $\mathrm{CD}^{+} \mathrm{T}$ cells are very effective in restricting viral spread during acute FV infection. They become exhausted by regulatory $\mathrm{T}$ cells and via the expression of inhibitory receptors during the transition phase between acute and chronic FV infection, leading to dysfunctional $\mathrm{CD}^{+} \mathrm{T}$ cells during persistent FV infection. Checkpoint blockade or depletion of regulatory $\mathrm{T}$ cells during chronic $\mathrm{FV}$ infection reactivates cytotoxic $\mathrm{CD}^{+} \mathrm{T}$ cells which then efficiently control persistent FV infection $(46,47)$. Type I IFNs can enhance the cytotoxicity of $\mathrm{CD}^{+} \mathrm{T}$ cells (34), but they can also increase the expression of inhibitory receptors and ligands like PD-1 or PD-L1 (48). Thus, we determined the effect of type I IFN treatment on $\mathrm{CD}^{+} \mathrm{T}$ cells during chronic FV infection as shown in Figure 2A. In accordance with previously published data (32) the percentages of $\mathrm{CD}_{4} 3^{+} \mathrm{CD}_{2} \mathrm{~L}^{-}$activated $\mathrm{CD}^{+} \mathrm{T}$ cells were increased during persistent FV infection compared to naïve mice (Figure 5A). The application of IFN $\alpha 11$ or IFN $\beta$ further increased the frequencies of activated $\mathrm{CD}^{+} \mathrm{T}$ cells. Interestingly, frequencies of GzmBexpressing activated $\mathrm{CD} 8^{+} \mathrm{T}$ cells as well as the expression levels of GzmB in activated $\mathrm{CD} 8^{+} \mathrm{T}$ cells were strongly enhanced after IFN $\alpha 11$ therapy, whereas the treatment with IFN $\beta$ had no effect on the expression of cytotoxic molecules during persistent $\mathrm{FV}$ infection (Figures 5B, C). In line with the $\mathrm{CD}^{+} \mathrm{T}$ cell data (Figures 4E-G), we did not observe any significant changes in the percentages of cytokine producing $\mathrm{CD}^{+} \mathrm{T}$ cells (Figures 5D-F) after type I IFN treatment. To verify that the increased GzmB expression also implicates higher cytotoxicity in the reactivated $\mathrm{CD}^{+} \mathrm{T}$ cells, we analyzed their potency to eliminate target cells in vivo. Therefore, we treated chronic FVinfected mice with either IFN $\alpha 11$ or IFN $\beta$ and at day 45 post infection, we adoptively transferred target cells loaded with an immunodominant epitope peptide derived from the FV Gag protein as well as unloaded cells as control. After two hours of incubation, killing of target cells by $\mathrm{FV}$-specific $\mathrm{CD} 8^{+} \mathrm{T}$ cells was determined in the spleen (Figure 6A). Depending on the 
A

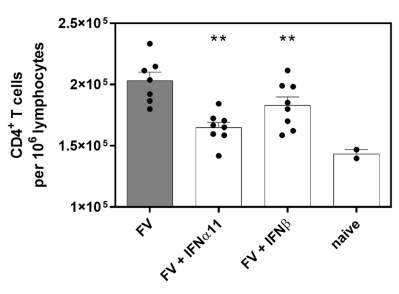

E

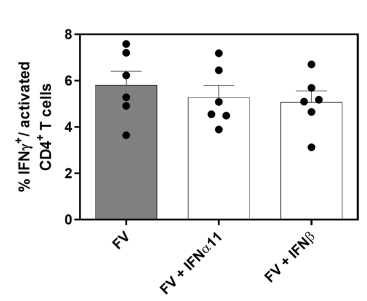

B

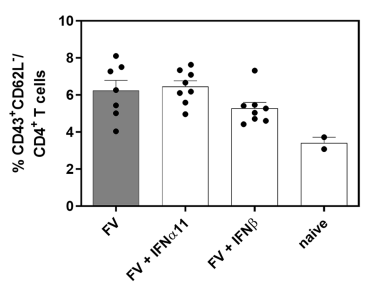

F

$\mathrm{IL}-2$ producing $\mathrm{CD}^{+} \mathrm{T}$ cells

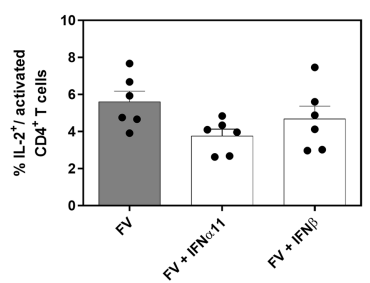

C

cytotoxic $\mathrm{CD}^{+} \mathrm{T}$ cells

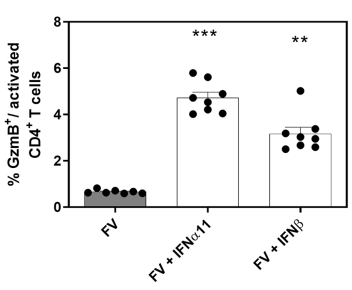

G

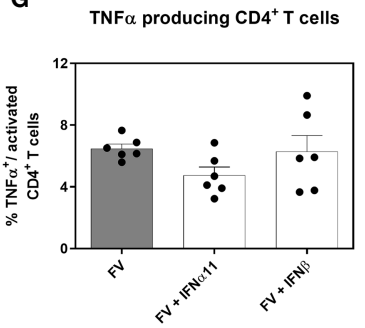

cytotoxic $\mathrm{CD}^{+} \mathrm{T}$ cells

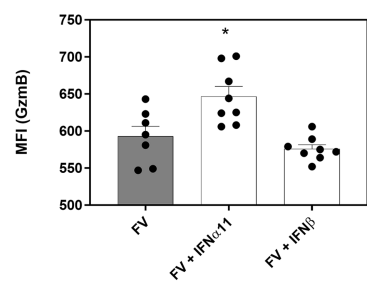

FIGURE 4 | Analysis of intracellular cytotoxic molecules and cytokine expression of CD4+ T cells in type I IFN-treated chronically FV-infected mice. C57BL/6 mice were infected with 20,000 SFFU of FV and additional 100,000 FFU of F-MuLV. Mice were treated daily with 8000 units of IFN $\alpha 11$ or IFN $\beta$ from day 40 to 44 mice. At day 45 post infection, mice were sacrificed and CD4 ${ }^{+} \mathrm{T}$ cell effector functions were analyzed by flow cytometry. Numbers of CD4 ${ }^{+} \mathrm{T}$ cells (A), percentages of CD43 CD62L-activated CD4 ${ }^{+}$T cells (B), percentages of intracellular expression determine of (C) GzmB and (D) individual GzmB expression (MFI) was determined. Multiparametric flow cytometry was used to measure percentages of intracellular expression of IFN $\gamma(\mathbf{E})$, IL-2 (F) and TNF $\alpha$ (G) in activated CD4 ${ }^{+}$T cells. Mean values (+SEM) are indicated by bars. Statistically significant differences between the IFN-treated groups and the untreated group were analyzed using Kruskal-Wallis oneway analysis and Dunn's multiple comparison and are indicated by * for $p<0.05$; ${ }^{\star \star}$ for $p<0.01 ;{ }^{* \star *}$ for $p<0.001$.

numbers of transferred target cells and the incubation time, we observed an elimination of $39.2 \% \pm 11.48$ of transferred target cells in persistent FV infected mice (Figure 6B). We assessed a significant increase in the killing capacity of FVspecific $\mathrm{CD}^{+} \mathrm{T}$ cells after treatment with IFN $\alpha 11(57.6 \% \pm$ 11.51). We also observed a slight increase in target-cell killing after IFN $\beta$ treatment $(51.1 \% \pm 7.1)$, however this was not statistically significant.

In conclusion, we observed an antiviral effect of IFN $\alpha 11$ and IFN $\beta$ during acute FV infection. In contrast, during chronic FV infection, only IFN $\alpha 11$ therapy was able to control FV replication. Apart from the likely direct antiviral activity of IFNo11 suggested by the induction of ISGs, treatment with IFN $\alpha 11$ reactivated dysfunctional $\mathrm{CD}^{+} \mathrm{T}$ cells, and augmented their cytotoxic effector function.

\section{DISCUSSION}

Although type I IFNs were shown to be antiviral in different acute viral infections, its role in persistent viral infections is controversially discussed. In this work, we could show that type I IFNs including IFN $\alpha$ and IFN $\beta$ controlled acute FV infection, whereas a therapeutic treatment during chronic FV infection was only beneficial after administration of IFN $\alpha$ (11). Interestingly, in contrast to its antiviral effect in vitro and in acute FV infection, application of recombinant IFN $\beta$ did not control persistent FV infection. Type I IFNs consist of numerous IFN $\alpha$ subtypes, IFN $\beta$, IFNe, IFNא and IFNל/limitin with broad pleiotropic biological effects including antiviral, antiproliferative, immunomodulatory, and regulatory properties. There are more and more publications showing an either beneficial or detrimental effect of type I IFNs for the host which depends on the pathogen, pathogen load, the timing, the infected cell type, and the type of IFN-producing cell. Careful detailed investigations of the unique properties of type I IFNs in different infection models are required to get a better understanding of type I IFN-mediated responses and their underlying mechanisms.

During chronic viral infections hyperimmune-activation, the expression of negative immune regulators (IL-10 and PD-L1), an increased IFN signature, and destruction of the lymphoid tissue architecture correlate with disease progression in LCMV, HIV/ SIV, or HCV infection (24, 49-51). Here, we did not detect an elevated IFN signature in the chronically FV-infected mice neither by systemic IFN $\alpha$ levels nor by mRNA expression of some key ISGs. The overall IFN response in untreated persistent FV-infected animals was comparable to the basal expression levels in uninfected controls. An induction of the immunoregulatory ligand PD-L1 was shown to increase on virus-infected cells during acute FV infection and that the expression of PD-L1 could be further increased upon type I IFN stimulation in vitro (52). However, during chronic FV infection the expression of PDL1 is comparable to baseline expression levels in naive mice (data not shown). Thus, during chronic Friend retroviral infection, the mice did not develop chronic hyperimmune-activation, elevated IFN signatures, or upregulated negative immune regulators. The host immune response during chronic FV infection is characterized by exhausted $\mathrm{FV}$-specific $\mathrm{CD}^{+} \mathrm{T}$ cells which can 

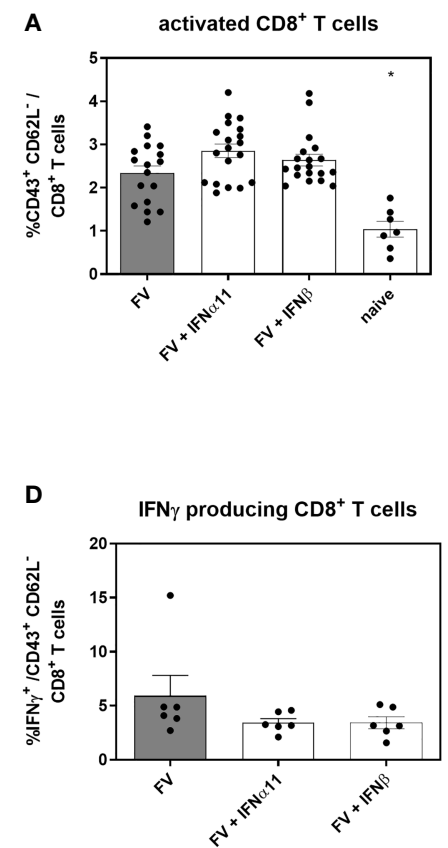
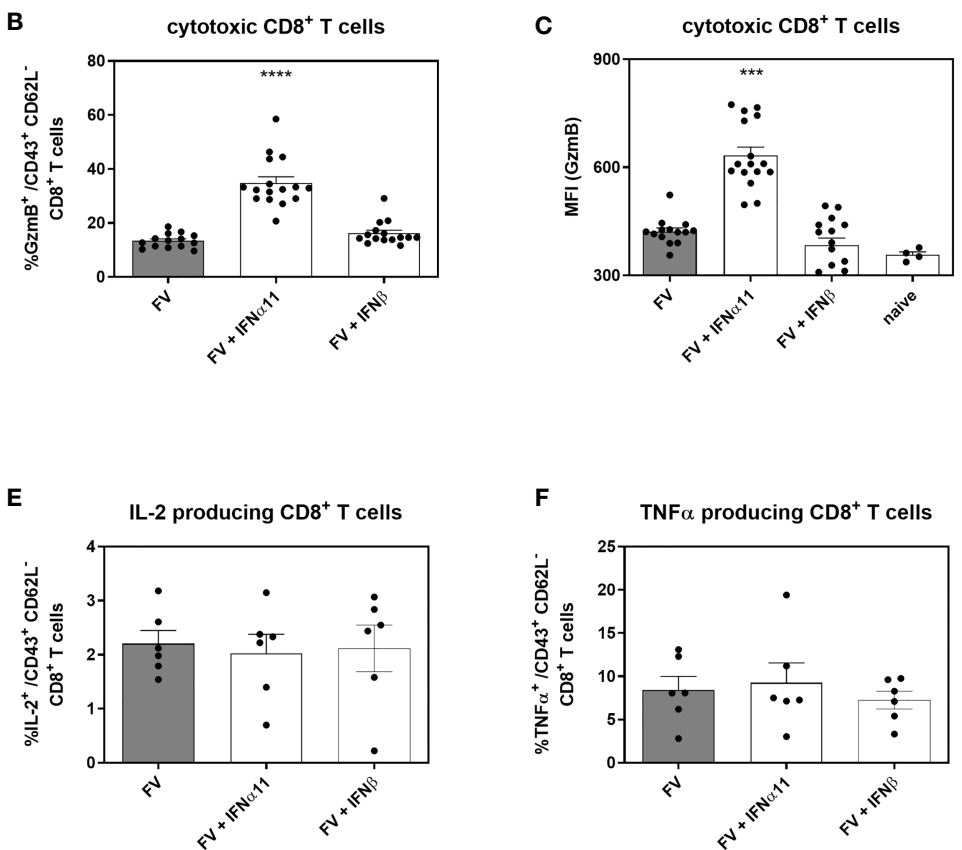

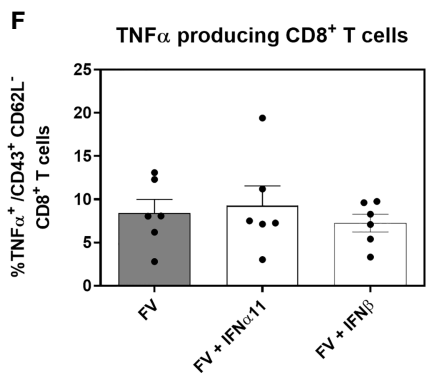

FIGURE 5 | Analysis of intracellular cytotoxic molecules and cytokine expression of CD8 ${ }^{+}$T cells in type I IFN-treated chronically FV-infected mice. C57BL/6 mice were infected with 20,000 SFFU of FV and additional 100,000 FFU of F-MuLV. Mice were treated daily with 8000 units of IFN 111 or IFN $\beta$ from day 40 to 44 mice. At day 45 post infection, mice were sacrificed and $\mathrm{CD}^{+} \mathrm{T}$ cell effector functions were analyzed by flow cytometry. Percentages of $\mathrm{CD} 43^{+} \mathrm{CD} 2 \mathrm{~L}^{-}$activated $\mathrm{CD}^{+} \mathrm{T}^{-}$ cells (A) and percentages of intracellular GzmB expression (B) and individual GzmB expression (MFI) was determined (C). Multi-parametric flow cytometry was used to measure percentages of intracellular expression of IFN $\gamma$ (D), IL-2 (E) and TNF $\alpha$ (F) in activated CD8 ${ }^{+}$T cells. Mean values (+SEM) are indicated by bars. Statistically significant differences between the IFN-treated groups and the untreated group were analyzed using Kruskal-Wallis one-way analysis and Dunn's multiple comparison and are indicated by ${ }^{\star}$ for $p<0.05$; ${ }^{\star \star \star}$ for $p<0.001$; ${ }^{\star \star \star \star}$ for $p<0.0001$.

be reactivated through Treg depletion or $\alpha$-PD-L1 antibody treatment $(32,46)$. Here, we could show that IFN 111 treatment in chronic FV infection, induced the expression of antiviral ISGs, but also stimulated exhausted $\mathrm{CD} 8^{+} \mathrm{T}$ cells that regained effector cell function.

To uncover the different biological roles of type I IFNs their impact on modulating host immune responses has to be identified in detail. In our study the therapeutic treatment with IFN $\alpha 11$ resulted in an increased cytotoxicity of $\mathrm{CD}^{+} \mathrm{T}$ cells shown by the expression of granzyme $\mathrm{B}$ and an improved target cell killing in vivo. In contrast, IFN $\beta$ did not increase the expression of granzyme B, but a trend to slight increase in target cell killing was observed which was not as strong as after IFN $\alpha 11$ treatment. Various immunomodulatory roles of type I IFNs were already described like activation of DCs, increased NK cell cytotoxicity, improved $\mathrm{T}$ cell effector functions, and activation of B cells $(27,36$, $37,43,44,53)$. In the current study, only differences in $\mathrm{T}$ cell responses were detected, as neutralizing antibody titers only slightly improved after IFN $\beta$ treatment in chronic FV infection and might therefore play a minor role in the beneficial outcome of the IFN-immunotherapy. In chronic LCMV infection IFN $\alpha$ was shown to control early viral dissemination, but it does not affect persistent viral infection (24). Interestingly, blocking of IFN $\beta$ but not IFN $\alpha$ improved antiviral $\mathrm{T}$ cell responses and reduced viral loads by decreasing the amounts of infected CD $8 \alpha^{-}$DCs and preventing disruption of the splenic architecture. In a previous study the authors also showed increased levels of the negative immunoregulators IL-10 and PD-L1 in $\alpha$ IFNAR-treated LCMVinfected mice (22). However, IFN $\beta$ blockade during persistent LCMV infection did not result in a reduction of PD-L1 expression of antigen-presenting cells or serum IL-10 level (24). We also did not detect any significant differences in PD-1/PD-L1 expression or systemic IL-10 levels after IFN $\beta$ therapy in chronic FV-infected mice (data not shown), which might explain the diverse activity of these two type I IFNs in persistent FV infection. We might speculate that the reduced direct antiviral activity by IFN $\beta$ (shown by no increase in ISG expression, Figure 3), and the slight effect on $\mathrm{T}$ cell cytotoxicity (Figures 4C, 6B) accounted for the significant therapeutic difference of IFN $\beta$ versus IFN $\alpha 11$ during chronic FV infection. However, this only accounted for chronic FV infection, as IFN $\beta$ therapy significantly reduced viral loads during acute FV infection. Another study in SIV-infected macaques describes the importance of timing and duration of an IFN-immunotherapy (54). Application of IFN $\alpha 2 \mathrm{a}$ initially upregulated the expression of antiviral genes and prevented a systemic SIV-infection. Longer treatments resulted in desensitization of type I IFNs and reduced ISG expression leading to an increased SIV reservoir size. This might account for all the different members of the type I IFN family as their unique biological activity might depend on infecting pathogen, infected tissue/cell type and the phase of the infection. The use of IFN $\alpha$ in the treatment of HIV-1 infection or as a cure strategy is 
A

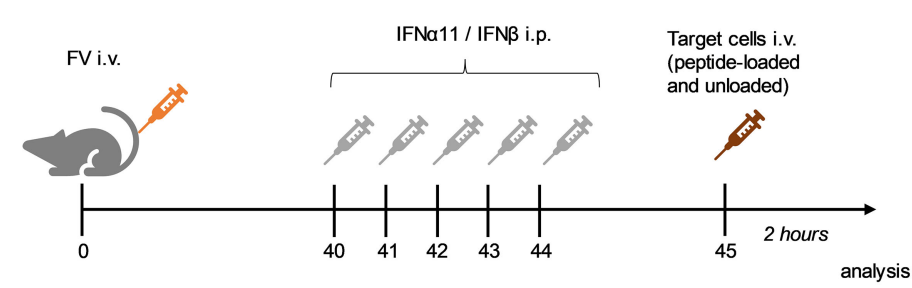

B

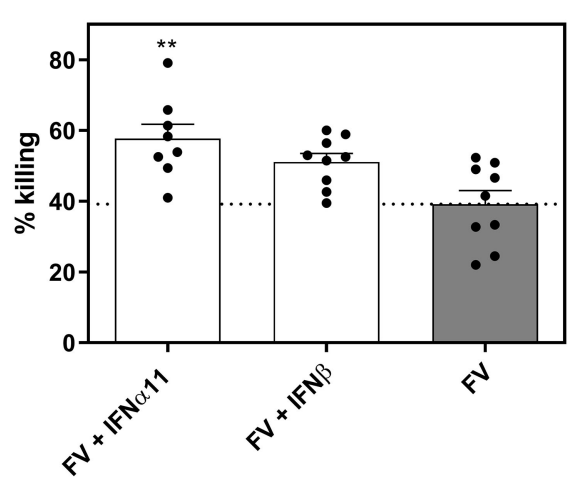

FIGURE 6 | Influence of IFN treatment on the cytotoxic activity of FV-specific CD8 ${ }^{+}$T cells in vivo. C57BL/6 mice were infected with 20,000 SFFU of FV and additional 100,000 FFU of F-MuLV. Mice were treated daily with 8000 units of IFN $\alpha 11$ or IFN $\beta$ from day 40 to 44 mice. At day 45 post infection, peptide-loaded and Cell Trace ${ }^{\mathrm{TM}}$ Violet-labeled target cells $\left(80 \mu \mathrm{M}\right.$, high) were mixed with unloaded and Cell Trace ${ }^{\mathrm{TM}}$ Violet-labeled target cells $(2 \mu \mathrm{M}$, low) in a ratio of $1: 1$ and were injected i.v. into FV-infected and IFN-treated mice. After 2 hours, mice were sacrificed and the killing capacity was determined. (A) The scheme of the experimental timeline is shown. (B) The percentages (+SEM) of target cell killing in spleen is shown. Statistically significant differences between the groups were tested using ordinary one way ANOVA and Tukey's multiple comparison and are indicated by ** for $p<0.01$.

controversial, particularly due to several studies blocking the IFN $\alpha / \beta$ receptor in HIV-1 infected humanized mice. One study using monoclonal antibodies to block IFNAR during persistent HIV infection demonstrated that, despite having increased viral loads upon blockade, IFNAR signaling may drive $\mathrm{CD}^{+} \mathrm{T}$ cell apoptosis and dysfunction of $\mathrm{CD}^{+}$and $\mathrm{CD} 8^{+} \mathrm{T}$ cells during chronic infection in humanized mice (20). Additionally, others reported that antiretroviral therapy combined with IFNAR blockade in HIV-1 infected humanized mice decreased plasma RNA levels as well as numbers of latently infected cells (19). In contrast to these studies that block all type I IFN-mediated effects including IFN $\alpha$ and IFN $\beta$-mediated antiviral and immunomodulatory effects, we and others have reported that specific IFN $\alpha$ subtypes can mediate beneficial effects in HIV-1 infected humanized mice $(10,12,55)$.

IFN $\alpha 2 a / b$ is clinically approved for the treatment against $\mathrm{HBV}$ and HCV; however, HCV infection is nowadays treated with direct acting antivirals, which are the safest and most effective medicines for treating hepatitis $\mathrm{C}$ with a success rate of more than $90 \%$. Immunotherapy with IFN $\alpha 2 \mathrm{a} / \mathrm{b}$ is important for the clinical treatment of chronic hepatitis B. IFN $\alpha$ exhibits direct antiviral effect as well as immunomodulatory activities, which can induce sustained antiviral responses in part of the treated chronic hepatitis B patients. IFN $\alpha 2 \mathrm{a} / \mathrm{b}$ therapy inhibits viral replication intermediates, blocks reinfection and improves clearance of infected hepatocytes through stimulation of immune cell responses. IFN $\alpha$ is also able to reduce the covalently closed circular DNA pool of HBV, but the HBsAg clearance rates after IFN $\alpha 2 \mathrm{a} / \mathrm{b}$ treatment are rather low (up to $30 \%$ ). Importantly, up to date only one IFN $\alpha$ subtype is approved for clinical treatment, and the unique and non-redundant antiviral and biological functions of the other eleven human IFN $\alpha$ subtypes are not considered at all. IFN $\beta$ is also approved for clinical treatment against multiple sclerosis (MS), but not as an antiviral drug. The underlying molecular mechanism of IFN $\beta$ in MS is still elusive, but some reports showed an increased production of antiinflammatory cytokines, decreased major histocompatibility complex II (MHC II) expression on antigen-presenting cells, a diminished lymphocyte activation, and reduced $\mathrm{T}$ cell migration through the blood-brain barrier (56-58). Similar effects were also observed in a mouse model of cerebral malaria in which treatment with IFN $\beta$ increased the survival rate of the mice and improved the blood-brain barrier function, but it did not alter the systemic parasitemia of Plasmodium berghei (59). These observations clearly describe a more regulatory function of IFN $\beta$, which was also reported elsewhere $(24,60,61)$ and which further confirmed our findings of IFN $\beta$ in chronic FV infection.

In conclusion, we could show that during persistent $\mathrm{FV}$ infection only the treatment with IFN $\alpha$ enables retroviral control, whereas recombinant IFN $\beta$ could only control acute FV infection. Our study demonstrates the pleiotropic biological activity of different type I IFNs, although they all bind to the same receptor and activate the same downstream signaling cascades. Further detailed analysis is required to fully understand the complexity of the type I IFN responses in viral infections.

\section{DATA AVAILABILITY STATEMENT}

The raw data supporting the conclusions of this article will be made available by the authors, without undue reservation.

\section{ETHICS STATEMENT}

The animal study was reviewed and approved by North RhineWestphalia State Agency for Nature, Environment and Consumer Protection (LANUV). 


\section{AUTHOR CONTRIBUTIONS}

KS and UD conceived of the study. MS, YS, AM, ZK, and JD substantially contributed to the acquisition and analysis of the data. TK contributed to the implementation of the research. KS wrote the original manuscript. All authors edited and approved the final manuscript.

\section{FUNDING}

This work was supported by the DFG RTG 1949 to KS and UD.

\section{SUPPLEMENTARY MATERIAL}

The Supplementary Material for this article can be found online at: https://www.frontiersin.org/articles/10.3389/fimmu.2021. 809774/full\#supplementary-material

\section{REFERENCES}

1. van Pesch V, Lanaya H, Renauld JC, Michiels T. Characterization of the Murine Alpha Interferon Gene Family. J Virol (2004) 78:8219-28. doi: 10.1128/JVI.78.15.8219-8228.2004

2. Zwarthoff EC, Mooren AT, Trapman J. Organization, Structure and Expression of Murine Interferon Alpha Genes. Nucleic Acids Res (1985) 13:791-804. doi: 10.1093/nar/13.3.791

3. Hardy MP, Owczarek CM, Jermiin LS, Ejdeback M, Hertzog PJ. Characterization of the Type I Interferon Locus and Identification of Novel Genes. Genomics (2004) 84:331-45. doi: 10.1016/j.ygeno.2004.03.003

4. Gibbert K, Schlaak J, Yang D, Dittmer U. IFN-Alpha Subtypes: Distinct Biological Activities in Anti-Viral Therapy. Br J Pharmacol (2013) 168:104858. doi: 10.1111/bph.12010

5. Platanias LC. Mechanisms of Type-I- and Type-II-Interferon-Mediated Signalling. Nat Rev Immunol (2005) 5:375-86. doi: 10.1038/nri1604

6. Perrillo R. Benefits and Risks of Interferon Therapy for Hepatitis B. Hepatology (2009) 49:S103-11. doi: 10.1002/hep.22956

7. Abdel-Mohsen M, Deng X, Liegler T, Guatelli JC, Salama MS, Ghanem Hel D, et al. Effects of Alpha Interferon Treatment on Intrinsic Anti-HIV-1 Immunity In Vivo. J Virol (2014) 88:763-7. doi: 10.1128/JVI.02687-13

8. Azzoni L, Foulkes AS, Papasavvas E, Mexas AM, Lynn KM, Mounzer K, et al. Pegylated Interferon Alfa-2a Monotherapy Results in Suppression of HIV Type 1 Replication and Decreased Cell-Associated HIV DNA Integration. J Infect Dis (2013) 207:213-22. doi: 10.1093/infdis/jis663

9. Asmuth DM, Murphy RL, Rosenkranz SL, Lertora JJ, Kottilil S, Cramer Y, et al. Safety, Tolerability, and Mechanisms of Antiretroviral Activity of Pegylated Interferon Alfa-2a in HIV-1-Monoinfected Participants: A Phase II Clinical Trial. J Infect Dis (2010) 201:1686-96. doi: 10.1086/652420

10. Lavender KJ, Gibbert K, Peterson KE, Van Dis E, Francois S, Woods T, et al. Interferon Alpha Subtype-Specific Suppression of HIV-1 Infection In Vivo. J Virol (2016) 90:6001-13. doi: 10.1128/JVI.00451-16

11. Harper MS, Guo K, Gibbert K, Lee EJ, Dillon SM, Barrett BS, et al. InterferonAlpha Subtypes in an Ex Vivo Model of Acute HIV-1 Infection: Expression, Potency and Effector Mechanisms. PloS Pathog (2015) 11:e1005254. doi: 10.1371/journal.ppat.1005254

12. Sutter K, Lavender KJ, Messer RJ, Widera M, Williams K, Race B, et al. Concurrent Administration of IFNalpha14 and cART in TKO-BLT Mice Enhances Suppression of HIV-1 Viremia But Does Not Eliminate the Latent Reservoir. Sci Rep (2019) 9:18089. doi: 10.1038/s41598-019-54650-9

13. Stylianou E, Aukrust P, Muller F, Nordoy I, Froland SS. Complex Effects of Interferon-Alpha on the Cytokine Network in HIV Infection-Possible
Supplementary Figure 1 | Type I IFN activity on ISRE Luc reporter cells. 3T3 ISRE Luc reporter cells were stimulated with different concentrations of IFN $\alpha 11$ and IFN $\beta$ for 4.5h. As control commercially available universal IFN $\alpha$ and IFN $\beta$ (PBL) were used. Luciferase activity was determined in relative light units (RLU). Three independent experiments were performed and are shown as individual data sets.

Supplementary Figure 2 | Serum type I IFN levels at different timepoints post IFN injection. C57BL/6 mice were treated with 8000 units of IFN $\alpha 11$ or IFN $\beta$. At 30, 90, and 240 min post injection, mice were sacrificed and type I IFN levels were measured in the serum by IFN $\alpha$-specific ELISA (A) and ISRE-dependent firefly luciferase activity (B). Statistically significant differences between the control group (0) and the groups of IFN-treated mice (IFN $\alpha 11$ or IFN $\beta$ ) were tested using KruskalWallis one-way and Dunn's multiple comparison and are indicated by * $\mathrm{p}<0.05$.

Supplementary Figure 3 | Neutralizing antibody titers in chronically FV-infected mice. C57BL/6 mice were infected with 20,000 SFFU of FV and additional 100,000 FFU of F-MuLV. Mice were treated daily with 8000 units of IFN $\alpha 11$ or IFN $\beta$ from day 40 to 44 post infection. At day 45 post infection, mice were sacrificed and serum samples were analyzed for neutralizing antibody titers. At least 8 mice per group from two individual experiments were analyzed and the mean values for each group are indicated by a bar (+SEM). Statistically significant differences between the control group (FV) and the groups of IFN-treated mice (FV + IFN $\alpha 11$ or FV + IFN $\beta$ ) were tested using Kruskal-Wallis one-way and Dunn's multiple comparison and are indicated by ${ }^{*} \mathrm{p}<0.05$.

Contribution to Immunosuppression. Cytokine (2001) 14:56-62. doi: 10.1006/cyto. 2000.0850

14. Sedaghat AR, German J, Teslovich TM, Cofrancesco JJr., Jie CC, Talbot CCJr., et al. Chronic CD4+ T-Cell Activation and Depletion in Human Immunodeficiency Virus Type 1 Infection: Type I Interferon-Mediated Disruption of T-Cell Dynamics. J Virol (2008) 82:1870-83. doi: 10.1128/ JVI.02228-07

15. Herbeuval JP, Nilsson J, Boasso A, Hardy AW, Kruhlak MJ, Anderson SA, et al. Differential Expression of IFN-Alpha and TRAIL/DR5 in Lymphoid Tissue of Progressor Versus Nonprogressor HIV-1-Infected Patients. Proc Natl Acad Sci USA (2006) 103:7000-5. doi: 10.1073/pnas.0600363103

16. Dianzani F, Castilletti C, Gentile M, Gelderblom HR, Frezza F, Capobianchi MR. Effects of IFN Alpha on Late Stages of HIV-1 Replication Cycle. Biochimie (1998) 80:745-54. doi: 10.1016/S0300-9084(99)80028-5

17. Agy MB, Acker RL, Sherbert CH, Katze MG. Interferon Treatment Inhibits Virus Replication in HIV-1- and SIV-Infected CD4+ T-Cell Lines by Distinct Mechanisms: Evidence for Decreased Stability and Aberrant Processing of HIV-1 Proteins. Virology (1995) 214:379-86. doi: 10.1006/viro.1995.0047

18. Audige A, Urosevic M, Schlaepfer E, Walker R, Powell D, Hallenberger S, et al. Anti-HIV State But Not Apoptosis Depends on IFN Signature in CD4+ T Cells. J Immunol (2006) 177:6227-37. doi: 10.4049/jimmunol.177.9.6227

19. Zhen A, Rezek V, Youn C, Lam B, Chang N, Rick J, et al. Targeting Type I Interferon-Mediated Activation Restores Immune Function in Chronic HIV Infection. J Clin Invest (2017) 127:260-8. doi: 10.1172/JCI89488

20. Cheng L, Yu H, Li G, Li F, Ma J, Li J, et al. Type I Interferons Suppress Viral Replication But Contribute to T Cell Depletion and Dysfunction During Chronic HIV-1 Infection. JCI Insight (2017) 2(12):e94366 (1-20). doi: 10.1172/jci.insight.94366

21. Cheng L, Ma J, Li J, Li D, Li G, Li F, et al. Blocking Type I Interferon Signaling Enhances T Cell Recovery and Reduces HIV-1 Reservoirs. J Clin Invest (2017) 127:269-79. doi: 10.1172/JCI90745

22. Teijaro JR, Ng C, Lee AM, Sullivan BM, Sheehan KC, Welch M, et al. Persistent LCMV Infection Is Controlled by Blockade of Type I Interferon Signaling. Science (2013) 340:207-11. doi: 10.1126/science.1235214

23. Wilson EB, Yamada DH, Elsaesser H, Herskovitz J, Deng J, Cheng G, et al. Blockade of Chronic Type I Interferon Signaling to Control Persistent LCMV Infection. Science (2013) 340:202-7. doi: 10.1126/science.1235208

24. Ng CT, Sullivan BM, Teijaro JR, Lee AM, Welch M, Rice S, et al. Blockade of Interferon Beta, But Not Interferon Alpha, Signaling Controls Persistent Viral Infection. Cell Host Microbe (2015) 17:653-61. doi: 10.1016/j.chom.2015.04.005

25. Kabat D. Molecular Biology of Friend Viral Erythroleukemia. Curr Top Microbiol Immunol (1989) 148:1-42. doi: 10.1007/978-3-642-74700-7_1 
26. Hasenkrug KJ, Dittmer U. The Role of CD4 and CD8 T Cells in Recovery and Protection From Retroviral Infection: Lessons From the Friend Virus Model. Virology (2000) 272:244-9. doi: 10.1006/viro.2000.0387

27. Gibbert K, Joedicke JJ, Meryk A, Trilling M, Francois S, Duppach J, et al. Interferon-Alpha Subtype 11 Activates NK Cells and Enables Control of Retroviral Infection. PloS Pathog (2012) 8:e1002868. doi: 10.1371/ journal.ppat.1002868

28. Li JP, D'Andrea AD, Lodish HF, Baltimore D. Activation of Cell Growth by Binding of Friend Spleen Focus-Forming Virus Gp55 Glycoprotein to the Erythropoietin Receptor. Nature (1990) 343:762-4. doi: 10.1038/343762a0

29. Gerlach N, Gibbert K, Alter C, Nair S, Zelinskyy G, James CM, et al. AntiRetroviral Effects of Type I IFN Subtypes In Vivo. Eur J Immunol (2009) 39:136-46. doi: 10.1002/eji.200838311

30. Bollati-Fogolin M, Muller W. Virus Free, Cell-Based Assay for the Quantification of Murine Type I Interferons. J Immunol Methods (2005) 306:169-75. doi: 10.1016/j.jim.2005.08.005

31. Dittmer U, Brooks DM, Hasenkrug KJ. Characterization of a Live-Attenuated Retroviral Vaccine Demonstrates Protection via Immune Mechanisms. J Virol (1998) 72:6554-8. doi: 10.1128/JVI.72.8.6554-6558.1998

32. Zelinskyy G, Dietze KK, Husecken YP, Schimmer S, Nair S, Werner T, et al. The Regulatory T-Cell Response During Acute Retroviral Infection Is Locally Defined and Controls the Magnitude and Duration of the Virus-Specific Cytotoxic T-Cell Response. Blood (2009) 114:3199-207. doi: 10.1182/blood2009-03-208736

33. Zelinskyy G, Kraft AR, Schimmer S, Arndt T, Dittmer U. Kinetics of CD8+ Effector T Cell Responses and Induced CD4+ Regulatory T Cell Responses During Friend Retrovirus Infection. Eur J Immunol (2006) 36:2658-70. doi: 10.1002/eji.200636059

34. Curtsinger JM, Valenzuela JO, Agarwal P, Lins D, Mescher MF. Type I IFNs Provide a Third Signal to CD8 T Cells to Stimulate Clonal Expansion and Differentiation. J Immunol (2005) 174:4465-9. doi: 10.4049/ jimmunol.174.8.4465

35. Havenar-Daughton C, Kolumam GA, Murali-Krishna K. Cutting Edge: The Direct Action of Type I IFN on CD4 T Cells Is Critical for Sustaining Clonal Expansion in Response to a Viral But Not a Bacterial Infection. J Immunol (2006) 176:3315-9. doi: 10.4049/jimmunol.176.6.3315

36. Kolumam GA, Thomas S, Thompson LJ, Sprent J, Murali-Krishna K. Type I Interferons Act Directly on CD8 T Cells to Allow Clonal Expansion and Memory Formation in Response to Viral Infection. J Exp Med (2005) 202:637-50. doi: 10.1084/jem.20050821

37. Dickow J, Francois S, Kaiserling RL, Malyshkina A, Drexler I, Westendorf $\mathrm{AM}$, et al. Diverse Immunomodulatory Effects of Individual IFNalpha Subtypes on Virus-Specific CD8(+) T Cell Responses. Front Immunol (2019) 10:2255. doi: 10.3389/fimmu.2019.02255

38. Hasenkrug KJ, Brooks DM, Dittmer U. Critical Role for CD4(+) T Cells in Controlling Retrovirus Replication and Spread in Persistently Infected Mice. J Virol (1998) 72:6559-64. doi: 10.1128/JVI.72.8.6559-6564.1998

39. Malyshkina A, Littwitz-Salomon E, Sutter K, Zelinskyy G, Windmann S, Schimmer S, et al. Fas Ligand-Mediated Cytotoxicity of CD4+ T Cells During Chronic Retrovirus Infection. Sci Rep (2017) 7:7785. doi: 10.1038/s41598-01708578-7

40. Chesebro B, Wehrly K. Identification of a non-H-2 Gene (Rfv-3) Influencing Recovery From Viremia and Leukemia Induced by Friend Virus Complex. Proc Natl Acad Sci USA (1979) 76:425-9. doi: 10.1073/pnas.76.1.425

41. Halemano K. Humoral Immunity in the Friend Retrovirus Infection Model. Immunol Res (2013) 55:249-60. doi: 10.1007/s12026-012-8370-y

42. Super HJ, Brooks D, Hasenkrug K, Chesebro B. Requirement for CD4(+) T Cells in the Friend Murine Retrovirus Neutralizing Antibody Response: Evidence for Functional T Cells in Genetic Low-Recovery Mice. J Virol (1998) 72:9400-3. doi: 10.1128/JVI.72.11.9400-9403.1998

43. Le Bon A, Schiavoni G, D'Agostino G, Gresser I, Belardelli F, Tough DF. Type I Interferons Potently Enhance Humoral Immunity and Can Promote Isotype Switching by Stimulating Dendritic Cells In Vivo. Immunity (2001) 14:46170. doi: 10.1016/S1074-7613(01)00126-1

44. Le Bon A, Thompson C, Kamphuis E, Durand V, Rossmann C, Kalinke U, et al. Cutting Edge: Enhancement of Antibody Responses Through Direct Stimulation of B and T Cells by Type I IFN. J Immunol (2006) 176:2074-8. doi: 10.4049/jimmunol.176.4.2074
45. Swanson CL, Wilson TJ, Strauch P, Colonna M, Pelanda R, Torres RM. Type I IFN Enhances Follicular B Cell Contribution to the T Cell-Independent Antibody Response. J Exp Med (2010) 207:1485-500. doi: 10.1084/jem.20092695

46. Dietze KK, Zelinskyy G, Liu J, Kretzmer F, Schimmer S, Dittmer U. Combining Regulatory T Cell Depletion and Inhibitory Receptor Blockade Improves Reactivation of Exhausted Virus-Specific CD8+ T Cells and Efficiently Reduces Chronic Retroviral Loads. PloS Pathog (2013) 9: e1003798. doi: 10.1371/journal.ppat.1003798

47. Dietze KK, Zelinskyy G, Gibbert K, Schimmer S, Francois S, Myers L, et al. Transient Depletion of Regulatory T Cells in Transgenic Mice Reactivates VirusSpecific CD8+ T Cells and Reduces Chronic Retroviral Set Points. Proc Natl Acad Sci USA (2011) 108:2420-5. doi: 10.1073/pnas.1015148108

48. Terawaki S, Chikuma S, Shibayama S, Hayashi T, Yoshida T, Okazaki T, et al. IFN-Alpha Directly Promotes Programmed Cell Death-1 Transcription and Limits the Duration of T Cell-Mediated Immunity. J Immunol (2011) 186:2772-9. doi: 10.4049/jimmunol.1003208

49. Bosinger SE, Li Q, Gordon SN, Klatt NR, Duan L, Xu L, et al. Global Genomic Analysis Reveals Rapid Control of a Robust Innate Response in SIV-Infected Sooty Mangabeys. J Clin Invest (2009) 119:3556-72. doi: 10.1172/JCI40115

50. Jacquelin B. Nonpathogenic SIV Infection of African Green Monkeys Induces a Strong But Rapidly Controlled Type I IFN Response. J Clin Invest (2009) 119:3544-55. doi: 10.1172/JCI40093

51. Wieland S, Makowska Z, Campana B, Calabrese D, Dill MT, Chung J, et al. Simultaneous Detection of Hepatitis C Virus and Interferon Stimulated Gene Expression in Infected Human Liver. Hepatology (2014) 59:2121-30. doi: 10.1002/hep. 26770

52. Akhmetzyanova I, Drabczyk M, Neff CP, Gibbert K, Dietze KK, Werner T, et al. PDL1 Expression on Retrovirus-Infected Cells Mediates Immune Escape From CD8+ T Cell Killing. PloS Pathog (2015) 11:e1005224. doi: 10.1371/journal.ppat.1005224

53. Biron CA. Activation and Function of Natural Killer Cell Responses During Viral Infections. Curr Opin Immunol (1997) 9:24-34. doi: 10.1016/S0952-7915(97)80155-0

54. Sandler NG, Bosinger SE, Estes JD, Zhu RT, Tharp GK, Boritz E, et al. Type I Interferon Responses in Rhesus Macaques Prevent SIV Infection and Slow Disease Progression. Nature (2014) 511:601-5. doi: 10.1038/nature13554

55. Abraham S, Choi JG, Ortega NM, Zhang J, Shankar P, Swamy NM. Gene Therapy With Plasmids Encoding IFN-Beta or IFN-Alphal4 Confers LongTerm Resistance to HIV-1 in Humanized Mice. Oncotarget (2016) 7:7841220. doi: 10.18632/oncotarget.12512

56. Graber J, Zhan M, Ford D, Kursch F, Francis G, Bever C, et al. InterferonBeta-1a Induces Increases in Vascular Cell Adhesion Molecule: Implications for Its Mode of Action in Multiple Sclerosis. J Neuroimmunol (2005) 161:16976. doi: 10.1016/j.jneuroim.2004.11.017

57. Teleshova N, Bao W, Kivisakk P, Ozenci V, Mustafa M, Link H. Elevated CD40 Ligand Expressing Blood T-Cell Levels in Multiple Sclerosis Are Reversed by Interferon-Beta Treatment. Scand J Immunol (2000) 51:312-20. doi: $10.1046 / j .1365-3083.2000 .00688 . x$

58. Jiang H, Milo R, Swoveland P, Johnson KP, Panitch H, Dhib-Jalbut S. Interferon Beta-1b Reduces Interferon Gamma-Induced Antigen-Presenting Capacity of Human Glial and B Cells. J Neuroimmunol (1995) 61:17-25. doi: 10.1016/0165-5728(95)00072-A

59. Morrell CN, Srivastava K, Swaim A, Lee MT, Chen J, Nagineni C, et al. Beta Interferon Suppresses the Development of Experimental Cerebral Malaria. Infect Immun (2011) 79:1750-8. doi: 10.1128/IAI.00810-10

60. Shaabani N, Vartabedian VF, Nguyen N, Honke N, Huang Z, Teijaro JR. IFNBeta, But Not IFN-Alpha, Is Responsible for the Pro-Bacterial Effect of Type I Interferon. Cell Physiol Biochem (2021) 55:256-64. doi: 10.33594/000000370

61. Perkins DJ, Rajaiah R, Tennant SM, Ramachandran G, Higginson EE, Dyson TN, et al. Salmonella Typhimurium Co-Opts the Host Type I IFN System To Restrict Macrophage Innate Immune Transcriptional Responses Selectively. J Immunol (2015) 195:2461-71. doi: 10.4049/jimmunol.1500105

Conflict of Interest: The authors declare that the research was conducted in the absence of any commercial or financial relationships that could be construed as a potential conflict of interest.

Publisher's Note: All claims expressed in this article are solely those of the authors and do not necessarily represent those of their affiliated organizations, or those of the publisher, the editors and the reviewers. Any product that may be evaluated in 
this article, or claim that may be made by its manufacturer, is not guaranteed or endorsed by the publisher.

Copyright (c) 2022 Schwerdtfeger, Dickow, Schmitz, Francois, Karakoese, Malyshkina, Knuschke, Dittmer and Sutter. This is an open-access article distributed under the terms of the Creative Commons Attribution License (CC BY). The use, distribution or reproduction in other forums is permitted, provided the original author(s) and the copyright owner(s) are credited and that the original publication in this journal is cited, in accordance with accepted academic practice. No use, distribution or reproduction is permitted which does not comply with these terms. 